\title{
ДЕКРИМІНАЛІЗАЦІЯ ОКРЕМИХ ЗЛОЧИНІВ, ЯК ОДИН ІЗ ШЛЯХІВ ПІДВИЩЕННЯ РІВНЯ БЕЗПЕКИ НА ЗАЛІЗНИЧНОМУ ТРАНСПОРТІ ТА ЗАБЕЗПЕЧЕННЯ ВІДШКОДУВАННЯ ЗБИТКІВ ВІД НЕСАНКЦІОНОВАНОГО ВТРУЧАННЯ В ДІЯЛЬНІСТЬ ОБ'ЄКТІВ КРИТИЧНОЇ ІНФРАСТРУКТУРИ
}

Чередниченко О.Ю., к.е.н., доцент, професор (Інститут підготовки юридичних кадрів для СБ Украӥни Національного юридичного університету імені Ярослава Мудрого), докторант (Украӥнський держкавий університет залізничного транспорту)

В статті розглядається питання пошуку варіантів поліпшення криміногенної обстановки на залізничному транспорті, зниження рівня несанкціонованого втручання в діяльність залізниці та можливості підвищення відшкодування матеріальних збитків від актів несанкиіонованого втручання. Проводиться аналіз статистичних показників, які відображають криміногенну обстановку на залізничному транспорті та надаються рекомендащії щзодо реформування окремих напрямків кримінальної юриспруденції. Розроблені пропозищії щзодо змін норм $i$ підходів в кримінальній юриспруденції з урахуванням кращого світового досвіду і стандартів, що позитивно вплине на безпековий стан об'єктів критичної інфраструктури Украӥни і в тому числі вітчизняного залізничного транспорту.

Ключові слова: безпека, несанкціоновані втручання в діяльність залізниці, залізнична галузь, криміногенна обстановка, кримінальний злочин, кримінальний проступок, кримінальна юриспруденція, реформування залізничної галузі.

\section{ДЕКРИМИНАЛИЗАЦИЯ ОТДЕЛЬНЫХ ПРЕСТУПЛЕНИЙ, КАК ОДИН ИЗ ПУТЕЙ ПОВЫШЕНИЯ УРОВНЯ БЕЗОПАСНОСТИ НА ЖЕЛЕЗНОДОРОЖНОМ ТРАНСПОРТЕ И ОБЕСПЕЧЕНИЯ ВОЗМЕЩЕНИЯ УЩЕРБА ОТ НЕСАНКЦИОНИРОВАННОГО ВМЕШАТЕЛЬСТВА В ДЕЯТЕЛЬНОСТЬ ОБЬЕКТОВ КРИТИЧЕСКОЙ ИНФРАСТРУКТУРЫ}

\begin{abstract}
Чередниченко А.Ю., к.э.н., доцент, профессор ( Институт подготовки юридических кадров для СБ Украины Национального юридического университета имени Ярослава Мудрого), докторант (УкрГУЖТ)
\end{abstract}

\begin{abstract}
В статье рассматривается вопрос поиска вариантов улучиения криминогенной обстановки на железнодорожном транспорте, снижения уровня несанкиионированного вмешательства в деятельность железной дороги и возможности повышения возмещуения материального ущерба от актов несанкционированного вмешательства. Проводится анализ статистических показателей, которые отражают криминогенную обстановку на железнодорожном
\end{abstract}


транспорте и предоставляются рекомендации по реформированию отдельных направлений уголовной юриспруденции. Разработаны предложения по изменениям норм и подходов в уголовной юриспруденции с учетом лучшего мирового опыта и стандартов, что положительно повлияет на безопасное состояние объектов критической инфраструктуры Украины и в том числе отечественного железнодорожного транспорта.

Ключевые слова: безопасность, несанкционированные вмешательства в деятельность железной дороги, железнодорожная отрасль, криминогенная обстановка, уголовное преступление, уголовный проступок, уголовная юриспруденция, реформирования железнодорожсной отрасли.

\title{
DECRIMINALIZATION OF CERTAIN CRIMES AS A WAY OF INCREASING THE LEVEL OF RAILWAY SAFETY AND ENSURING COMPENSATION OF DAMAGE FROM UNAUTHORISED INTERFERENCE WITH CRITICAL INFRASTRUCTURE
}

\author{
Cherednychenko O.U., PhD in Economics (Juridical Personnel Training \\ Institute for the Security Service of Ukraine, Yaroslav Mudryi National Law \\ University)
}

The article considers the issue of searching for options for improving the criminal situation on the railway transport, reducing the level of unauthorized interference in the activities of the railway and the possibility of increasing compensation for material damage from acts of unauthorized interference. The analysis of statistical indicators that reflect criminogenic situation in railway transport and provides recommendations for reforming certain areas of criminal jurisprudence. The introduction of decriminalization of certain categories of non-serious crimes will provide an opportunity to quickly and factually not only document offenses, but also to bring the culprit to justice, and this will speed up the process of reimbursing material damage, significantly increasing the preventive effect, primarily by increasing the percentage of the inevitability of punishments. The developed proposals on changes in norms and approaches in criminal jurisprudence take into account the best world experience and standards, which will positively affect the safety of critical infrastructure facilities in Ukraine, including domestic rail transport.

Keywords: safety, of unauthorized interference in the operations of the railway, the railway industry, crime, criminal offence, criminal offense, criminal law, reform of the railway industry.

Постановка проблеми та ї̈ зв'язки з науковими чи практичними завданнями. Залізничний транспорт виробничо-технологічний комплекс організацій і підприємств залізничного транспорту загального користування, призначений для забезпечення потреб суспільного виробництва i населення країни в перевезеннях у внутрішньому i міжнародному сполученнях та надання інших транспортних послуг усім споживачам без обмежень за ознаками форми власності та видів діяльності тощо [1]. Серед великої кількості завдань, які необхідно розв'язувати транспортникам в сучасних умовах - $є$ проблема збереження в безпечному, робочому стані інфраструктури, рухомого складу, вантажів, забезпечення безпеки пасажирів. Особливої актуальності це набуває на тлі погіршення криміногенної ситуації в державі. Як зазначають в ПАТ «Укрзалізниця», наразі залізнична інфраструктура майже щодня зазнає 
пошкоджень унаслідок дій сторонніх осіб. Однією із таких проблем є різке зростання кількості, так званих, «нетяжких злочинів» (крадіжки, пошкодження майна, дрібне хуліганство та ін.). Зловмисники викрадають кабель залізничної сигналізації та зв'язку, дросельтрансформатори, розбирають обладнання верхньої будови колії, через вандалізм страждають вікна пасажирських поїздів та лінзи світлофорів тощо. Щороку ця ситуація погіршується, i залізничникам усе складніше власними силами забезпечувати збереженість інфраструктури та вантажів. За даними ПАТ «Укрзалізниця» лише за перші два місяці 2017 року залізниця зазнала майже 9 млн. грн. збитків від крадіжок, що втричі більше, ніж за цей же період у 2016 році [2].

В сучасних умовах проблема несанкціонованих втручань в діяльність залізничного транспорту вийшла за рамки «безпеки руху потягів» i набула політичних, соціальних $\mathrm{i}$ економічних ознак. Збитки від втручань сторонніх осіб (крадіжки, розукомплектування машин, обладнання, механізмів, елементів інфраструктури, наслідки терактів, диверсій, ДТП і т.д.), а також витрати на їх усунення збільшують витрати на виробничу діяльність, впливають на рівень доходності залізниць, зменшують прибуток i як наслідок негативно впливають на сплату податків, інших соціальних виплат [3].

За прогнозами фахівців, 3 урахуванням погіршенням криміногенної обстановки (зростанням злочинності), падінням соціально-економічного рівня населення ситуація покращуватися не буде. Тому у ПАТ «Укрзалізниця» вважають, що вирішувати цю проблему треба не лише силами залізничників, але й iз залученням правоохоронних органів, місцевих адміністрацій та громадськості.

До основних причин, що сприяють несанкціонованому втручанню в діяльність залізничного транспорту, а саме крадіжкам, пошкодженням майна, хуліганським діям відносяться:

недосконалість законодавчо-

нормативної бази, в частині невідворотності покарання, складний механізм щодо документування та притягнення до відповідальності;

неможливість охоплення засобами фізичної охорони всіх уразливих об'єктів транспортної інфраструктури; ліквідація підрозділів транспортної міліції, передача їх функцій територіальним органам національної поліції i, як наслідок, збільшення навантаження на їх співробітників;

- психологічна нестійкість та відсутність моральних принципів, відсутність патріотичничних та корпоративних принципів у працівників, пасажирів, громадян;

\section{недосконалість}

попереджувально-профлактичних заходів; зниження професійного рівня співробітників правоохоронних органів, їх слабка мотивація щодо виконання посадових обов'язків.

Першочергового вирішення потребують питання усунення недоліків законодавчо-нормативної бази, в частині невідворотності покарання, складності механізму щодо документування та притягнення до відповідальності, що i обумовлює необхідність більш ретельного розгляду напрямків вирішення окреслених проблем.

Аналіз останніх досліджень $i$ публікацій та виділення невирішених частин загальної проблеми. Проблемам безпеки на залізничному транспорті присвячені праці таких вчених як В.Л. Дикань, І.В. Воловельська [4], М.В. Корінь [5], І.Л. Назаренко, Т.Г. Сухорукова [6] , А.В. Толстова [7], О.В. Шраменко [8], у тому числі вирішують питання протидії несанкціонованого втручання в діяльність залізничного транспорту О.Ю. Чередниченко [3], М.М. Чеховська [9] та інші. 
Проблемою реформування кримінальної юриспруденції займаються такі вчені як В.Ю. Шепітько [10], О.Г. Шило [11], В.Я. Тацій [12], О.М. Бандурка [13] та інші. В той же час, існує багато питань за вказаними напрямками, які потребують додаткового дослідження.

Метою cmammi $є$ аналіз причин підвищення кількості актів несанкціонованого втручання в діяльність залізничного транспорту та надання пропозицій щодо варіантів поліпшення ситуації шляхом внесення змін в кримінальній юриспруденції, зокрема пов'язаних 3 декриміналізацією окремих статей кримінального кодексу i переформатування системи кримінального процесу та системи виконання покарань.

Виклад основного матеріалу. До першочергових заходів, що дозволять сформувати систему протидії несанкціонованому втручанню в роботу залізничного транспорту пропонуємо віднести:

перегляд законодавчих та нормативних та приведення механізмів їх застосування до реалій сьогодення;

надання правоохоронним

органам реальних можливостей щодо застосування окремих норм кримінальних та адміністративних кодексів;

\section{активізація}

попереджувально-профілактичної роботи щодо можливостей запобігання несанкціонованим втручанням в діяльність залізничного транспорту, насамперед шляхом демонстрації невідворотності покарань;

реальне запровадження

заходів щодо компенсації товариству заподіяних злочинцями матеріальних збитків.

На даний час за несанкціоноване втручання в роботу залізниць передбачене наступне покарання:

за пошкодження залізничної колії, захисних лісонасаджень, снігозахисних огорож та інших об'єктів, споруд і пристроїв сигналізації та зв'язку накладається штраф від 170 грн. до 510 грн., а на посадових осіб - від 340 грн. до 1020 грн.;

за підкладання на залізничні колії предметів, які можуть спричинити порушення руху поїздів, - від 255 грн до 680 грн;

за пошкодження

внутрішнього обладнання пасажирських вагонів - від 170 грн. до 510 грн.;

- за умисне руйнування або

пошкодження шляхів сполучення,

рухомого складу, засобів зв'язку чи

сигналізації зловмисники караються штрафом від 850 грн. до 4250 грн. або виправними роботами на строк до двох років, чи позбавленням волі строком до трьох років [14].

Автором дослідження навмисно бралися до уваги нетяжкі злочини, так як саме така категорія правопорушень масово споюється на об'єктах транспортної інфраструктури i як наслідок може призвести до серйозних негативних наслідків у разі їх ігнорування чи не розслідування.

Зрозуміло, що вищенаведені штрафні санкції не можуть забезпечити відшкодування заподіяної шкоди i, насамперед не із-за невеликих сум штрафів, а із-за того, що існуючий нині порядок притягнення правопорушника до відповідальності передбачає складний механізм документування злочину в рамках кримінального провадження. А кількість скоєних такого роду правопорушень ще більш ускладнює доведення розслідування до суду де саме i виноситься вирок, в тому числі у вигляді накладення штрафу чи відшкодування матеріальних збитків. В результаті процент розгляду нетяжких кримінальних правопорушень в суді дуже невеликий у порівнянні 3 правопорушеннями що реєструються. А це призводить не тільки до уникнення від відповідальності, а й стимулює зріст злочинності в результаті порушення принципу невідворотності покарання. В таблиці наводяться офіційні 
статистичні дані, які відображають стан переконливо свідчать про необхідність щодо злочинності в Україні та негайного покращення ситуації.

Таблиияя

Стан злочинності в Украӥні [15]

\begin{tabular}{|c|c|c|c|}
\hline Рік & $\begin{array}{c}\text { Всього виявлено } \\
\text { злочинів }\end{array}$ & $\begin{array}{c}\text { Всього засуджено } \\
\text { осіб }^{2}\end{array}$ & $\begin{array}{c}\text { Кількість осіб, } \\
\text { притягнутих до } \\
\text { адміністративної } \\
\text { відповідальності, } \\
\text { (тис. осіб) }\end{array}$ \\
\hline 2013 & 563560 & 122973 & 4249,9 \\
\hline 2014 & $529139^{5}$ & $102170^{6}$ & $2657,0^{6}$ \\
\hline 2015 & $565182^{7}$ & $94798^{6}$ & $1984,6^{6}$ \\
\hline 2016 & $592604^{7}$ & $76217^{6}$ & $2183,6^{6}$ \\
\hline
\end{tabular}

13а даними Генеральної прокуратури України.

23а даними Державної судової адміністрації України.

33а даними Державної служби України з надзвичайних ситуацій.

${ }^{4}$ Станом на 20.11.2012.

5Ураховуючи дані тимчасово окупованої території Автономної Республіки Крим та м. Севастополя за січень-березень 2014 р. та всі повідомлення про злочини, які вчинені на тимчасово окупованій території та зареєстровані іншими територіальними органами досудового розслідування.

${ }^{6}$ Без урахування тимчасово окупованої території Автономної Республіки Крим, м. Севастополя та частини зони проведення антитерористичної операції.

${ }^{7}$ Ураховуючи всі повідомлення про злочини, які вчинені на тимчасово окупованій території та зареєстровані іншими територіальними органами досудового розслідування.

Намагання України долучитися до європейської спільноти, спонукає країну впроваджувати європейські стандарти не тільки в економіці, обороні, а й правоохоронній діяльності. Впровадження або перехід кримінальної юстиції на стандарти країн ЄС в свою чергу потребує переформатування кримінального процесу. Проведення реформ в системі правоохоронних органів та суду повинно не тільки ставити за мету їх осучаснення, а й приведення до більш ефективного використання фінансових засобів, яких нині бракує, впровадження системи їх більш ефективної роботи. Одним із таких напрямків реформування системи правоохоронного сектору держави $\epsilon$ декриміналізація ряду злочинів, зміни порядку досудового розслідування певної категорії злочинів.

Так, в листопаді 2017 року в Верховній Раді України було зареєстровано два законопроекти №7279 «Про внесення змін в окремі законодавчі акти України щодо спрощення досудового розслідування окремих категорій кримінальних правопорушень» [16] i аналогічний, альтернативний законопроект №7279-1 [17], основними завданнями яких $\epsilon$ декриміналізація окремих злочинів та введення поняття кримінальних проступків. До речі, ще при прийнятті в 2012 році нової редакції кримінально-процесуального кодексу України, в його заключних положеннях відмічалося про необхідність введення , так званого, інституту кримінальних проступків, а для реалізації цього необхідно прийняття окремого спеціального закону.

Автори законопроекту №7279 пропонують вважати кримінальний проступок різновидом кримінального правопорушення, за скоєння якого передбачається кримінальна відповідальність. Причому запропоновано в ст.12 Кримінального кодексу України виключити поняття злочину невеликої тяжкості, надав йому ознаки кримінального проступку, а осіб 
засуджених за скоєння кримінального проступку та тих, що вже відбули покарання, запропоновано вважати такими що не мають судимості.

Також, законодавці пропонують змінити порядок досудового розслідування такого виду правопорушень. Спростити порядок досудових розслідувань кримінальних проступків, на думку авторів законопроекту №7279 призваний, так званий, інститут дізнання, який ще треба бути створити. До речі, інститут дізнання не $\epsilon$ новим явищем для вітчизняної юриспруденції. Він існував до реформування кримінального процесу, але мав певні відмінності від запропонованого законодавцем варіанту. Крім того, автори вказаного законопроекту вважають за доцільне скоротити строки дізнання, які на їх думку не повинні перевищувати місяць 3 дня повідомлення про підозру. Ще однією новелою, вказаних перетворень, $\epsilon$ пропозиція щодо підвищення розміру заподіяної шкоди, 3 якої настає кримінальна відповідальність. На сьогодні вона складає 0,2 неоподаткованого податком мінімуму доходів громадян, тобто 160 грн. Автори цього законопроекту, на нашу думку, справедливо вважають що ця сума невідповідна сумі затрат, яку виділяє держава на проведення слідчих дій. Законодавці пропонують, і з цим підходом ми також погоджуємося, що суму 3 якої наступає кримінальна відповідальність, необхідно підвищити до 1 неоподаткованого податком мінімуму, а саме на сьогодні до 800 грн. Таким чином, великий масив правопорушень, перейде до сфери адміністративної відповідальності.

Автори альтернативного законопроекту №7279-1 вважають, що проступок це не злочин, за який особа повинна бути ізольована від суспільства, а покарання повинно бути у вигляді штрафу або максимум обмежитися виправними роботами. Мотивують вони тим, що при скоєнні вказаних правопорушень, як правило, не може бути заподіяно значної шкоди i, як наслідок, не може бути судимості. Також, на їх думку немає сенсу i у створенні органів дізнання, розслідування вказаної категорії правопорушень може здійснюватися не обов'язково слідчими, а й іншими співробітниками-правоохоронцями, які мають відповідну кваліфікацію. Крім того, автори альтернативного законопроекту №7279-1 пропонують відкриття провадження в суді в період проведення підготовчого засідання. В результаті сторона, що звинувачується може бути непідготовленої до захисту. На нашу думку, підхід який передбачає спрощення процедур розгляду кримінальних провопоступків може привести до втрати принципу змагання сторін. Також, автори вказаного законопроекту не виключають можливість розгляду обвинувачувального акту в суді при відсутності сторін і у випадку беззаперечувального зізнанні своєї вини. Це положення слід визначити суперечливим, так як воно не кореспондує 3 кращими міжнародним стандартам в галузі права та може скомпрометувати сузилля нашої країни щодо реформування кримінальної юриспруденції. Наприклад, в ЄС навпаки намагаються особу, що скоїла незначне правопорушення, особливо за незначні право-вчинки, сурово не карати, а спонукати іiі до мирової угоди із дією механізму компенсації потерпілій стороні нанесеної шкоди, матеріальної допомоги тощо.

В той же час, розробка вказаних законопроектів, незважаючи на їх протиріччя та недоліки, є кроком вперед. Було б за доцільне робочим групам спільно напрацювати єдиний законопроект, 3 урахуванням найкращих запропонованих ними норм, які відповідають стандартам міжнародного права. Важливою умовою $\epsilon$ i те, щоб запропоновані норми закону «працювали в наших умовах», тобто одночасно необхідно розробити і дієвий механізм їх реалізації. 
В результаті ми досягнемо не тільки певної гуманізації кримінального процесу, а й зможемо реально підвищити ефективність роботи слідчих шляхом зменшення навантажень, так званих «дрібних правопорушень», таких як дрібні крадіжки» і т.ін. Крім того, це дозволить досягти і певної економії бюджетних коштів, а саме не витрачати кошти на проведення окремих слідчих дій, наприклад проведення експертиз, вартість яких значно може перевищувати нанесену шкоду та відволікати експертів від необхідності першочергового проведення експертиз за тяжкі злочини і т.ін.

Невипадково можливість реалізації наведених змін в кримінальній юриспруденції проілюстрована саме на прикладі залізничної галузі, бо залізнична транспортна система загального користування, без урахування промислового залізничного транспорту, сягає 30,3 тис. кілометрів колії. Вона охоплює всю територію країни. Для вантажних операцій відкрито 1684 станції. Обслуговування пасажирів здійснюється на 126 вокзалах, 1684 станціях, 4749 платформах маршрутів приміського сполучення. Таким чином, майже все населення нашої держави користується послугами залізниці i, як наслідок, $\epsilon$ потенційними об'єктами щодо злочинних посягань.

У
вищевикладених

запровадження перетворень, а саме декриміналізації окремих категорій нетяжких злочинів, на нашу думку надасть можливість реально та швидко не тільки документувати правопорушення, а й притягувати винного до відповідальності. Також це прискорить процес повернення чи відшкодовувати матеріальних збитків, значно підвищить профілактичний ефект, насамперед шляхом збільшення відсотка невідворотності покарань.

Враховуючи те, що слідчими національної поліції за 2017 рік розслідувалося більше 2 млн. кримінальних проваджень, то середнє навантаження на слідчого складає 300 кримінальних проваджень [18]. Декриміналізації окремих категорій нетяжких злочинів дозволить кваліфікованим слідчим зосередитися на розслідування тяжких злочинів, підвищити якість їх розкриття шляхом зменшення «навантаження».

Висновки. Вирішення питань безпеки, мінімізації несанкціонованих втручань в діяльність залізниці неможливо без тісної взаємодії та співпраці 3 правоохоронними органами, місцевим населенням та патріотично налаштованими громадянами. Автор статі та фахівці ПАТ «Укрзалізниця» переконані, що врегулюванню цієї ситуації на законодавчому рівні сприятиме посиленню правового захисту стратегічної інфраструктури держави, активізація розслідувань кримінальних протиправних посягань у сфері залізничного транспорту та посилення відповідальності за злочинні посягання на майно залізничного транспорту.

Викладені пропозиції, на нашу думку, можливо запровадити не тільки на об'єктах залізничного транспорту, а й на інших об'єктах критичної інфраструктури держави.

\section{ПЕРЕЛІК ВИКОРИСТАНИХ ЖЕРЕЛ}

1. Про залізничний транспорт: закон України від 4 липня 1996 р. № 273/96-ВР // Відомості Верховної Ради України. - 1996. - № 40. - Ст. 183.

2. Крадіжки на залізниці набувають масштабів соціальної проблеми [Електронний ресурс]. - Режим доступу: https://www.ukrinform.ua/rubriceconomy/2193752-kradizki-na-zaliznicinabuvaut-masstabiv-socialnoi-problemiuz.html

3. Чередниченко О.Ю. Удосконалення діяльності 3 протидії та нейтралізації загроз від несанкціонованого втручання в системі економічної безпеки 
залізничного транспорту / О.Ю. Чередниченко // Вісник економіки транспорту і промисловості. -2016. - №54. - C. 263-267.

4. Дикань В.Л. Специфические особенности системы обеспечения экономической безопасности железнодорожного транспорта / В.Л. Дикань, И.В. Воловельськая // Науковий вісник Херсонського державного університету. Сер. : Економічні науки. 2016. - Вип. 16(4). - С. 63-66.

5. Корінь М.В. Теоретичні засади підвищення рівня технологічної безпеки залізничного транспорту / M.В. Корінь, В.М. Кривда // Вісник економіки транспорту і промисловості. -2017. - № 59. - C. 68-75.

6. Назаренко І.Л. Методика оцінки рівня економічної безпеки дистанції колії / І.Л. Назаренко, Т.Г. Сухорукова // Вісник економіки транспорту і промисловості. -2014. - № 48. - C. 64-69.

7. Толстова А. В. Залізничний комплекс України як основа економічної безпеки країни / А.В. Толстова // Вісник економіки транспорту і промисловості. 2012. - №37. - С. 75-78.

\section{8. Шраменко}

O.B.

Забезпечення інфраструктурної безпеки залізничного транспорту / О.В.Шраменко // Вісник економіки транспорту i промисловості. - 2016. - № 56. - С.113118.



$$
\text { 10. Шепітько }
$$

B.Ю.

Трансформації в кримінальному процесі та деякі тенденції криміналістики в сучасних умовах / В.Ю. Шепітько // Науковий вісник Львівської комерційної академії. Серія : Юридична. - 2015. - Вип. 1. - C. 201-207.
11. Шило О.Г. До питання запровадження інституту слідчого судді в кримінальному процесі України / О.Г. Шило // Університетські наукові записки. 2011. - № 3. - С. 306-313.

12. Тацій В.Я. Ще одна спроба «гуманізації» кримінального законодавства України / В.Я. Тацій, В.І. Тютюгін, Ю.В. Гродецький, А.О. Байда // Вісник Асоціації кримінального права України. - 2014. - № 1. - С. 310-328.

13. Бандурка О.M. Теорія i практика оперативно-розшукової діяльності / О.М. Бандурка. - Харків: Золота миля. 2012. - 620 с.

14. За несанкціоновані втручання в роботу залізничного транспорту передбачена адміністративна i кримінальна відповідальність [Електронний ресурс]. - Режим доступу: http://www.uz.gov.ua/press_center/latest_ne ws/379337/

15. Стан злочинності в Україні [Електронний ресурс]. - Режим доступу: www.ukrstat.gov.ua

16. Проект Закону про внесення змін до деяких законодавчих актів України щодо спрощення досудового розслідування окремих категорій кримінальних правопорушень. Номер, дата реєстрації: 7279 від 10.11.2017 р. [Електронний ресурс]. - Режим доступу: w1.c1.rada.gov.ua/pls/zweb2/webproc4_1?pf $3511=62859$

17. Проект Закону про внесення змін до деяких законодавчих актів України щодо спрощення досудового розслідування окремих категорій кримінальних правопорушень. Номер, дата реєстрації: 7279-1 від 16.11.2017 р. [Електронний ресурс]. - Режим доступу: w1.c1.rada.gov.ua/pls/zweb2/webproc4_1?pf $3511=62902$

18. Правоохоронці розслідували майже 2 млн справ у 2017 році [Електронний ресурс]. - Режим доступу: https://prm.ua/u-2017-pravoohorontsirozsliduvali-mayzhe-2-mln-sprav/ 